CAHIER DE RECHERCHE $\# 0902 E$

Département de science économique

Faculté des sciences sociales

Université d'Ottawa
WORKING PAPER \#0902E

Department of Economics

Faculty of Social Sciences

University of Ottawa

\title{
Assessing the Redistributive Impact of Higher Education Tuition Fees Reforms: The Case of Québec ${ }^{\#}$
}

\author{
Paul Makdissi $^{*}$ and Myra Yazbeck ${ }^{* *}$
}

March 2009

\footnotetext{
\# We wish to thank Mathieu Audet for assistance with the data. We also wish to thank the Regroupement des étudiantes et étudiants de maîtrise, de diplôme et de doctorat de l'Université de Sherbrooke (REMDUS) and the Fédération étudiante universitaire du Québec (FEUQ) for having asked the first author to analyze this question.

* Department of Economics, University of Ottawa, 55 Laurier E. (10125), Ottawa, Ontario, Canada, K1N 6N5; Email: paul.makdissi@uottawa.ca

** Département d'économique, Pavillon de Sève, Université Laval, Québec, Canada, G1K 7P4; Email: myazbeck@ecn.ulaval.ca
} 


\begin{abstract}
In this article, we analyze the redistributive impact of a recent reform of tuition fees in Quebec. We adapt Duclos, Makdissi and Wodon's (2005) methodology to a Generalized Lorenz framework. Many policy analysts argued that maintaining low higher education tuition fees is regressive. We take a look at the empirical validity of this argument using data from Statistics Canada's Survey of Labor and Income Dynamics. We show the importance of using data to validate this argument. The results obtained allow for the conclusion that this redistributive argument is empirically not verified for the Province of Québec.
\end{abstract}

Keywords: Higher Education, Tuition fees, Inequality

JEL Codes : I22, I28, I38

\title{
Résumé
}

Dans cet article, nous analysons l'impact distributif d'une réforme récente des frais de scolarité au Québec. Nous adaptons la méthodologie de Duclos, Makdissi et Wodon (2005) à un cadre de courbes de Lorenz généralisées. Plusieurs analystes de politiques publiques arguent que le maintien de frais de scolarité faible pour les programmes d'éducation supérieure est une politique publique régressive. Nous analysons la validité empirique de cet argument en utilisant les données de l'Enquête sur la dynamique du travail et du revenu de Statistiques Canada. Nous démontrons l'importance d'effectuer une validation ce genre d'argument à l'aide de données empiriques. Les résultats obtenus nous permettent de conclure que cet argument distributif n'est pas valide pour la province de Québec.

Mots-clé: Éducation supérieure ; frais de scolarité ; inégalité

Classification JEL: I22, I28, I38 


\title{
Assessing the Redistributive Impact of Higher Education Tuition Fees Reforms: The Case of Québec*
}

\author{
Paul Makdissi ${ }^{\dagger}$ \\ Myra Yazbeck ${ }^{\ddagger}$ \\ University of Ottawa \\ Université Laval
}

March 2009

\footnotetext{
*We wish to thank Mathieu Audet for assistance with the data. We also wish to thank the Regroupement des étudiantes et étudiants de maîtrise, de diplôme et de doctorat de l'Université de Sherbrooke (REMDUS) and the Fédération étudiante universitaire du Québec (FEUQ) for having asked the first author to analyze this question.

$\dagger$ Department of Economics, University of Ottawa, 55 Laurier E. (10125), Ottawa, Ontario, Canada, K1N 6N5; Email: paul.makdissi@uottawa.ca

${ }^{\ddagger}$ Département d'économique, Pavillon de Sève, Université Laval, Québec, Canada, G1K 7P4; Email:myazbeck@ecn.ulaval.ca
} 


\title{
Résumé
}

Dans cet article, nous analysons l'impact distributif d'une réforme récente des frais de scolarité au Québec. Nous adaptons la méthodologie de Duclos, Makdissi et Wodon (2005) à un cadre de courbes de Lorenz généralisées. Plusieurs analystes de politiques publiques arguent que le maintien de frais de scolarité faible pour les programmes d'éducation supérieure est une politique publique régressive. Nous analysons la validité empirique de cet argument en utilisant les données de l'Enquête sur la dynamique du travail et du revenu de Statistiques Canada. Nous démontrons l'importance d'effectuer une validation ce genre d'argument à l'aide de données empiriques. Les résultats obtenus nous permettent de conclure que cet argument distributif n'est pas valide pour la province de Québec.

Mots-clés et expressions: Éducation supérieure, frais de scolarité, inégalité.

Classification JEL: I22, I28, I38

\begin{abstract}
In this article, we analyze the redistributive impact of a recent reform of tuition fees in Quebec. We adapt Duclos, Makdissi and Wodon's (2005) methodology to a Generalized Lorenz framework. Many policy analysts argued that maintaining low higher education tuition fees is regressive. We take a look at the empirical validity of this argument using data from Statistics Canada's Survey of Labor and Income Dynamics. We show the importance of using data to validate this argument. The results obtained allow for the conclusion that this redistributive argument is empirically not verified for the Province of Québec.
\end{abstract}

Keywords: Higher Education, Tuition fees, Inequality

JEL Codes: I22, I28, I38 


\section{Introduction}

Public spending on education has been considered a good vehicle of inequality reduction. However, the redistributive impact of this public spending varies with the targeted level of education. Given that children from low income families represent a larger share of the student body in primary schools, spending in primary education is more progressive than spending on higher education. In their paper, Moussaly-Sergieh and Vaillancourt (2007) go fur-

ther and argue that public spending on higher education in Québec might be regressive per se. The authors think that the poor are possibly paying taxes to subsidize higher education of children from richer families. Despite the logical nature of their argument, their inference is based on an illustrative theoretical example based on a two households society. Two major studies use this illustrative theoretical example for policy recommendation purposes. In fact, Lacroix and Trahan (2007) and Montmarquette, Facal and Lachapelle (2008) argue that the provincial government should raise university tuition fees. Without further evidence on the redistributive impact of a tuition fees increase, this recommendation has been implemented by the Liberal government with the support of the two opposition parties. Starting September 2007, tuition fees increased by $100 \$$ per year for five consecutive years. However, despite the availability of data in Canada and the existence of a large body of literature on income distribution, no study has tried to assess the impact of this increase of tuition fees on inequality in the Province of Québec.

The objective of this paper is to fill this gap in the literature in an attempt to provide evidence on the real impact of this increase in university tuition fees. To answer this question, we adapt Duclos, Makdissi and Wodon's (2005) framework to a Lorenz dominance approach (Atkinson, 1970 and Shorrocks, 
1983). Using data from Statistics Canada's Survey of Labor and Income Dynamics 2002 (SLID), we show that, this policy reform increases inequality in the Province of Québec and that the illustrative argument in the above mentioned studies is empirically not verified in the context of Québec1. The remainder of the paper is organized as follows. Section 2 presents the analytical framework. Section 3 presents the empirical analysis and the section 4 concludes.

\section{Analytical framework}

Let us assume that social welfare is measured by an additive social welfare index

$$
U=\int_{\beta}^{y^{\max }} u(y) f(y) d y
$$

where $y$ is the equivalent income 2 and $f(y)$ is the density of this equivalent income defined over $\left[0, y^{\max }\right]$. For the purpose of this discussion we will focus on social welfare indices that are inequality adverse. Formally, those indices belong to class $\Omega^{2}$, defined as

$$
\Omega^{2}=\left\{U \mid u\left(y^{E}\right) \in C^{2},(-1)^{i+1} u^{(i)}\left(y^{E}\right) \geq 0 \text { for } i=1 \text { and } 2\right\},
$$

where $C^{2}$ is the set of continuous functions that are 2-time differentiable over $\Re_{+}$. The normative interpretation of the conditions in (2) is the following. The welfare indices weakly increase $\left(u^{(1)}\left(y^{E}\right) \geq 0\right)$ when a consumer's equivalent income increases. These indices are thus Paretian but

\footnotetext{
${ }^{1}$ See Atemnkeng Johannes, Akwi and Etoh Anzah (2006) for an opposite result in the context of a developing country

${ }^{2}$ Following King (1983), assume that $y$ be pre-reform real income assessed using prereform prices as reference prices. In this context $y$ is a money-metric indicator of welfare: in King's terminology, it is also called "equivalent" income. As noted by King, the concept of equivalent income function is also used by McKenzie (1956), Samuelson (1974) and Varian (1980).
} 
they also obey the well-known symmetry or anonymity axioms: interchanging any two consumers' incomes leaves the social welfare indices unchanged. They also respect the Pigou-Dalton principle of transfers, which postulates that a mean-preserving transfer of income from a higher-income consumer to a lower-income consumer increases social welfare.

Comparing social welfare indices for two different distributions can be achieved using Generalized Lorenz Curve. These curves are defined as

$$
G L(p)=\int_{0}^{F^{-1}(p)} y d y
$$

where $F(y)=\int_{0}^{y} f(x) d x$ is the cumulative distribution of income. Consider two distributions $F_{A}$ and $F_{B}$, Shorrocks (1983) shows that social welfare is higher in a distribution $F_{A}$ that in a distribution $F_{B}$ for all social welfare indices $U \in \Omega^{2}$ if $G L_{A}(p) \geq G L_{B}(p)$ for all $p \in[0,1]$.

The objective of this paper is not to compare two distributions of wellbeing but to assess the impact of a public spending reform on well-being. In this context, it is important to assess the impact of a reform on the initial Generalized Lorenz Curve in order to compare pre and post reform social welfare. This kind of comparison can be made by adapting Duclos et al.'s (2005) framework to this Generalized Lorenz context. Let $t_{H E}(y)$ denote the average monetary cost of higher education per student from a household with income $y$. The proportion of the population at income $y$ that benefits from higher education is given by $\tau_{H E}(y)$. A "targeting function" can then be defined as

$$
\phi_{H E}(y)=\tau_{H E}(y) \cdot f(y) \text {. }
$$

$\Phi_{H E}=\int_{0}^{a} \phi_{H E}(y) d y \leq 1$ denotes the overall share of the population that benefits from higher education. The cumulative distribution function $G_{H E}(y)$ 
of benefit recipients is given by

$$
G_{H E}(y)=\frac{\int_{0}^{y} \phi_{H E}(x) d x}{\Phi_{H E}}
$$

and the density of recipients is then

$$
g_{H E}(y)=\frac{d G_{H E}(y)}{d y}=\frac{\phi_{H E}(y)}{\Phi_{H E}} .
$$

Mean public spending on higher education across the population is given by

$$
T_{H E}=\int_{0}^{a} t_{H E}(y) \phi_{H E}(y) d y .
$$

Assume that the government increases marginally by the same amount, $\triangle t_{H E}$, the tuition fees of every higher education student. The expected impact of this marginal reform for an individual with equivalent income $y$ is given by $-g(y) \triangle t_{H E}$. It is then straightforward to asses the impact on the Generalized Lorenz Curve:

$$
\triangle_{t_{H E}} G L(p)=-\triangle_{H E} C_{H E}(p),
$$

where $C_{H E}=\int_{0}^{F^{-1}(p)} g(y) d y$ is the concentration curve of the number of higher education students. The inspection of (8) indicates that the Generalized Lorenz Curves shifts downwards for a positive $\triangle t_{H E}$. This result implies an unambiguous loss of welfare. However, this increase in tuition fees increases government revenues and generates surpluses that can be allocated elsewhere.

Let us suppose that the surpluses generated by the tuition fees increase are allocated on tax reduction. Let us also assume that the government marginally decreases taxes by an amount of $-\Delta t_{I T}$ on average. This tax

\footnotetext{
${ }^{3} \mathrm{By}$ the envelope theorem, this is regardless of whether the agent changes his behavior following the reform. This is because income here is a money-metric indictor of welfare and not nominal income.
} 
reduction is allocated to individuals in proportion to their income. The actual tax relief that an individual with income $y$ enjoys is given by $-\left(y / \mu_{y}\right) \cdot \Delta t_{I T}$, where $\mu_{y}$ is the average income 4 . It is then straightforward to asses the impact of this tax reduction on the Generalized Lorenz Curve:

$$
\triangle_{t_{I T}} G L(p)=-\triangle t_{I T} L(p),
$$

where $L(p)=(1 / \mu) \cdot \int_{0}^{F^{-1}(p)} y d y$ is the Lorenz curve of income. The inspection of (9) indicates that the Generalized Lorenz Curves shifts upwards for any negative $\Delta t_{I T}$. This result implies an unambiguous gain of welfare.

In order to assess the overall welfare change, we must compare the welfare loss due to (8) to the gain due to (9). To do so, we assume that this reform is performed in a balanced budget framework so that the reduction of public funding in higher education is totally reallocated into tax reductions. Let us denote by $B$ the public budget. The impact of the above proposed program reform on this public budget is given by

$$
d B=\frac{\partial B}{\partial t_{H E}} \Delta t_{H E}+\frac{\partial B}{\partial t_{I T}} \Delta t_{I T}
$$

Assuming budget neutrality, we have $d B=0$, and we may define an economic efficiency ratio $\gamma$ for additional expenditures on the two programs as

$$
\gamma=\frac{\left(\partial B / \partial t_{H E}\right) / T_{H E}}{\left(\partial B / \partial t_{I T}\right) / T_{I T}}
$$

where $T_{I T}$ is the per capita tax. The numerator in (11) gives the cost in government resources per dollar spend on higher education subsidies. The denominator gives the same indicator for a tax relief.

Using revenue neutrality, (8) and (9), we get

$$
d G L(p)=-\triangle t_{H E} T_{H E}\left[C_{H E}(p)-\gamma L(p)\right] .
$$

\footnotetext{
${ }^{4}$ This assumption is consistent with the findings of Vermaeten, Gillespie and Vermaeten (1994) who show that the overall tax incidence in Canada is proportional to income.
} 
This leads to the following result:

Proposition 1 The revenue-neutral higher education tuition fee reform will reduce welfare for all welfare indices $U \in \Omega^{2}$ if

$$
C_{H E}(p)-\gamma L(p) \geq 0 \text { for all } p \in[0,1] .
$$

\section{Analysis of Québec's Reform}

The Canadian context represents an interesting environment to study the impact of tuition fees subsidies on social welfare. Although higher education is subsidized everywhere in Canada, there is a lot of heterogeneity in tuition fees on the provincial level. Table 1 gives some examples of tuition fees across provinces. As we can see, the province of Québec has the lowest tuition fees. However, starting from September 2007, tuition fees increased by $100 \$$ per year for five consecutive years. The method presented in the previous section enables us to analyze the impact of marginal reforms in general. Using the envelope theorem, the analysis can be done using directly the information contained in a household survey. However, it is important to note that, as pointed out by Lanjouw and Ravallion (1999), non marginal changes in the size of a public program may affect the capture of the program by different socioeconomic groups. Assuming that higher tuition fees will change the future relative representation of socioeconomic groups in the student body, it is interesting to analyze the impact of a tuition fees reform in Canada as a whole and in Québec alone. This will give a hint on the expected changes in the relative representation of socioeconomic groups in the student body.

To analyze the impact of the proposed reform in Québec, we use the Survey of Labor and Income Dynamics (SLID) published by Statistics Canada for 2002. This survey contains the information on the number of person 


\begin{tabular}{|l|c|}
\hline Province & Tuition fees \\
\hline \hline British Columbia & $5405 \$$ \\
\hline Alberta & $5455 \$$ \\
\hline Ontario & $6213 \$$ \\
\hline Québec & $2519 \$$ \\
\hline Canadian average & $\mathbf{5 0 0 0} \$$ \\
\hline
\end{tabular}

Table 1: Tuition fees 2006-2007.

attending higher education in the household. Although we do not have information on the program of study, we can still assess the redistributive impact of the actual reform because, from equation (8), the only required information is the proportion of person attending higher education at each level of income.

To make the equivalent incomes comparable across geographical areas, we use the implicit deflators developed in Makdissi and Groleau (2002). When considering family composition and size, we use an equivalence scale to make income comparable across heterogenous households. Let us denote by $x_{i}$ total household income, we have $y_{i}=x_{i} / n_{e}$ with :

$$
n_{e}=\left[n_{a}+\varphi n_{c}\right]^{\beta},
$$

where $n_{e}$ is the number of equivalent adults in the household, $n_{a}$ is the number of adults in the household and $n_{c}$ is the number of children. The parameter $\varphi$ is used to differentiate the cost of a child compared to an adult. Cutler and Katz (1992), who proposed this equivalence scale, indicate that there exists a consensus that this parameter should be around 0.40 . We use this value. The parameter $\beta$ represents the extent of economies of scale in larger households. As it is frequently the case in the literature, we use $\beta=0.5$.

Figure 1 shows the dominance test for Canada. Although the concentration curve for the number of students initially is above the Lorenz curve, 


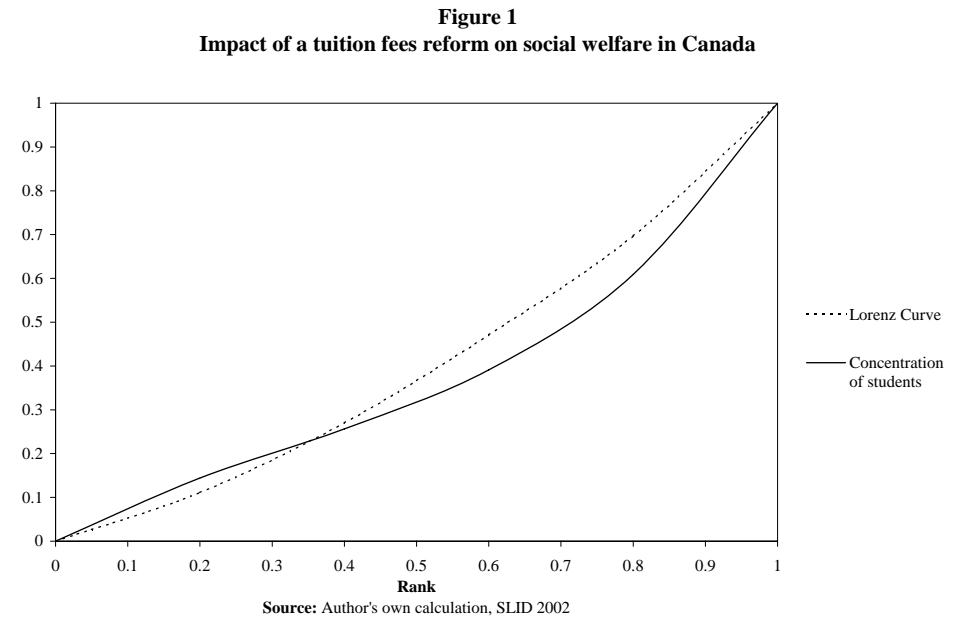

both curves cross. This violate the dominance condition. It is therefore impossible to conclude unambiguously that the reform increases or decreases social welfare 5 .

Figure 2 shows the dominance test for Québec. In this case, the concentration curve for the number of students is everywhere above the Lorenz curve. This means that, if we assume that there is no difference in the economic cost of subsidizing tuition fees compared to the economic cost of lowering taxes, then the reform adopted by the government of Québec will reduce social welfare for all social welfare indices that have the property of inequality aversion. It is impossible to build a social welfare index that increases with the above mentioned reform.

At this point it is worth to try to understand what explains the difference

\footnotetext{
${ }^{5}$ It is however possible to assume that there is a subset of indices with high inequality aversion for which this reform will be deemed as regressive by all indices in this subset. See Makdissi and Mussard (2008).
} 


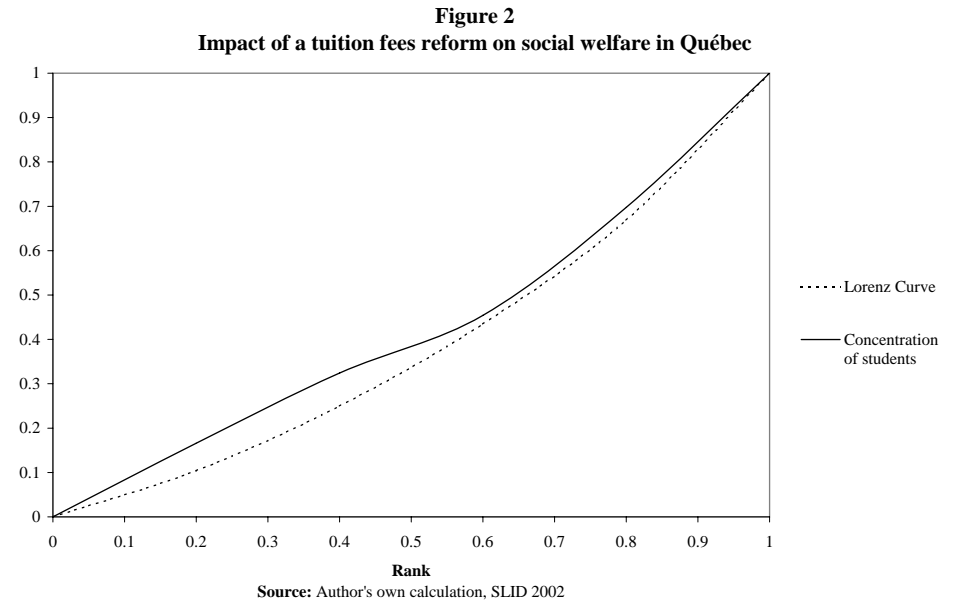

between the results obtained for Canada as a whole and those obtained for the province of Québec? Essentially, we may infer from the concentration curve that the difference lies in the proportion of students that come from lower income households. In Québec, those students represent a higher share of the student body. This is consistent with the findings of Paulsen and St.John (2002) who show that the impact of a $1000 \$$ increase of tuition fees in the U.S.A. has 5 to 6 times more impact on higher education attendance of lower class students than on students from the highest socioeconomic class.

\section{Conclusion}

In this article, we have analyzed the impact of a recent tuition fees reform on social welfare in the province of Québec. Adapting Duclos et al.'s (2005) methodology to the Generalized Lorenz framework, we conclude that the 
redistributive argument that was laid down to justify the reform is empirically invalid in the specific context of Québec. The empirical validity of such an argument is essentially linked to the structure of the household data and can be answered only empirically.

Further research is needer to understand the redistributive impact of non marginal changes in tuition fees as well as in other aspects of student financial aid, such as scholarships, bursaries and student loans.

\section{References}

[1] T. Atemnkeng Johannes, T. Akwi and P. Etoh Anzah (2006), The Distributive Impact of Fiscal Policy in Cameroon : Tax and Benefit Incidence, PMMA Working Paper 2006-16.

[2] Atkinson, A. B. (1970), On the Measurement of Inequality, Journal of Economic Theory, 2, 244-263.

[3] Cutler, D. and L. Katz (1992), Rising Inequality? Changes in the Distribution of Income and Consumption in the 1980's, AER Papers and Proceedings, 82, 546-551.

[4] Duclos, J.-Y., P. Makdissi and Q. Wodon (2005), Poverty-Dominant Transfer Programs: The Role of Targeting and Allocation Rules, Journal of Development Economics, 77, 53-73.

[5] King, M.A. (1983), Welfare Analysis of Tax Reforms Using Household Data, Journal of Public Economics, 21, 183-214.

[6] Lacroix, R. and M. Trahan (2007), Le Québec et les droits de scolarité universitaire, CIRANO Rapport Bourgogne 2007RB-01. 
[7] Lanjouw, P. and M. Ravallion (1999), Benefit Incidence, Public Spending Reforms, and the Timing of Program Capture, World Bank Economic Review, 13, 257-273.

[8] Makdissi, P. and Y. Groleau (2002), Que pouvons-nous apprendre des profils de pauvreté canadiens?, Actualité économique - Revue d'analyse économique, Vol. 78, No. 2, pp. 257-286.

[9] Makdissi, P. and S. Mussard (2008), Analyzing the Impact of Indirect Tax Reforms on Rank-Dependent Social Welfare Functions: A Positional Dominance Approach, Social Choice et Welfare, 30, 385-399.

[10] McKenzie, L. (1956), Demand Without a Utility Index, Review of Economic Studies, 24, 185-189.

[11] Montmarquette, C., J. Facal and L. Lachapelle (2008), Mieux tarifer pour mieux vivre ensemble, Rapport du groupe de travail sur la tarification des services publics, Government of Quebec.

[12] Mousally-Sergieh, K. and F. Vaillancourt (2007), Le financement des institutions d'enseignement post-secondaire au Québec, 1961-2005, McGill Journal of Education, 42, 427-442.

[13] Paulsen, M.B. et E.P. St. John (2002), Social Class and College Costs: Examining the Financial Nexus Between College Choice and Persistance, Journal of Higher Education, 189-236

[14] Samuelson, P.A. (1974), Complementarity - An Essay on the 40th Anniversary of the Hicks-Allen Revolution in Demand Theory, Journal of Economic Literature, 12, 1255-1289. 
[15] Shorrocks, A.F. (1983), Ranking Income Distributions, Economica, 50, $3-17$.

[16] Varian, H. (1980), Notes on Cost-Benefit Analysis, mimeo.

[17] Vermaeten, F., W.I. Gillespie and A. Vermaeten (1994), Tax Incidence in Canada, Canadian Tax Journal, 42, 384-416. 